Ole Petter Vestheim

Nord universitet

DOI: http://dx.doi.org/10.5617/adno.6249

\title{
Nasjonale prøver - hemmende styringsverktøy eller lokale redskap for praksisutvikling?
}

\section{Sammendrag}

Artikkelen bygger på empiri fra en studie som hadde til hensikt å undersøke hva som kjennetegner praksis(er) på skoler som over tid har oppnådd gode resultater på nasjonale prøver. Studiens hensikt var å utvikle forskningsbasert kunnskap om forhold som er av betydning for å lykkes på de nasjonale prøvene og avdekke hvilken plass prøvene hadde i skolenes praksis. Data ble innhentet med bruk av kvalitative singel- og gruppeintervjuer med rektorer og lerere fra sju skoler. Det teoretiske perspektivet og funnene i studien bidrar til å kaste lys over hvordan nasjonale prøver, som inngår i skolenes praksisarkitekturer, bidrar til praksisutvikling.

Nøkkelord: standardiserte prøver, nasjonale prøver, skoleutvikling, praksis, praksisarkitekturer

\section{National tests - inhibitory management tools or local tools for practice development?}

\begin{abstract}
The article is based on empirical evidence from a study that intended to investigate what characterizes practice(s) in schools that have achieved good results in national tests over time. The purpose of the study was to develop research-based knowledge about conditions that are important for the success in the national tests and to reveal the place that the tests had in the practice of the schools. Data was obtained using qualitative single and group interviews with principals and teachers from seven schools. The theoretical perspective and the findings in the study help to shed light on how national tests, which are part of the schools' practice architectures, contribute to practice development.
\end{abstract}

Keywords: standardized tests, national tests, school development, practice, practice architectures 


\section{Innledning}

I løpet av de siste tiårene har det internasjonalt vært stor økning i og fokus på bruk av tester for å måle elevers læringsutbytte og måloppnåelse (Tveit, 2014). Den økte bruken av internasjonale og nasjonale standardiserte tester har endret både rammeverket for skolens praksiser og praksisene som utspiller seg på den enkelte skole (se f.eks. Barrett, 2009; Berliner, 2011; Biesta, 2009; Lowrie \& Diezmann, 2009; Mausethagen, 2013b; Stauffer \& Mason, 2013; Vestheim, 2017; Vestheim \& Lyngsnes, 2016). Det er over et tiår siden nasjonale prøver ble innført i det norske utdanningssystemet. Likevel er det relativt lite forskning som har belyst konsekvenser av implementeringen. Dette til tross for at prøvene blant annet er ment å fungere som et verktøy i kvalitetsarbeidet på ulike nivåer i utdanningssystemet (Utdanningsdirektoratet, 2016). Prøvene bidrar helt konkret med kunnskap om hvordan den enkelte elev klarer å løse et sett med oppgaver i de grunnleggende ferdighetene lesing, regning og engelsk på et bestemt nivå. I etterkant av gjennomføring av prøvene blir deretter disse dataene å anse som en del av skolens potensielle kunnskapsgrunnlag. Kunnskapsgrunnlaget kan tas i bruk til vurdering av skolens praksis med hensikt å utvikle den hvis det blir ansett som nødvendig. Nødvendigheten av å eventuelt endre praksis vurderes derimot ikke bare av den enkelte skole eller aktør i skolen, men avgjøres i spennet der de nasjonale prøvene på den ene siden fungerer som et styringsverktøy og på den andre siden som kunnskapsressurs lokalt på den enkelte skole. Det kan stilles spørsmål ved om denne dobbeltheten virker hemmende for kreativ kunnskapsutvikling og formativ utvikling av skolens praksis (Hermansen \& Mausethagen, 2016, s. 104), eller om den eventuelt kan virke fremmende. I så fall vil det være hensiktsmessig å undersøke hvordan en hemmende eller fremmende praksis utspiller seg.

Mausethagen, Prøitz og Skedsmo (2018) fant i en studie at lærere bruker en bred kunnskapsbase basert på både interne og eksterne elementer i møter der hensikten er å vurdere skolens praksis. De trekker fram blant annet erfaringsbasert og fagdidaktisk kunnskap. I tillegg anvendes kunnskap som bygger på deres forhold til eleven, foresatte og selvsagt egne kolleger. Disse kvalitativt «tykke» dataene anvendes så i sammenheng med for eksempel data fra tester («tynne» data), som kan være en pådriver for praksiser som har til hensikt å kritisk diskutere eksisterende og framtidig undervisningspraksis (Mausethagen et al., 2018, s. 46). Gunnulfsen og Roe (2018) viser i sin studie at det er stor variasjon i hvordan nasjonale prøver blir brukt og hvordan de blir oppfattet av lærere og ledere i skolen. Studien antyder at det er en moderat til sterk sammenheng mellom hvordan rektorer tilrettelegger for anvendelse av prøvene og lærernes praksis og holdning til prøvene.

Vestheim og Lyngsnes (2016) viser i sin forskning at lærerne på skoler som har oppnådd gode resultater på nasjonale prøver over tid uttrykker å befinne seg i et spenningsforhold mellom på den ene siden skepsis og mistenksomhet til 
prøvene og på den andre siden at prøvene er et av flere sentrale elementer i utvikling av skolenes praksiser. Som Mausethagen et al. (2018, s. 46-47) hevder, er det et behov for mer kunnskap om hvordan lærere og rektorer rammer inn resultatmøter, og hvorvidt slike møter eller praksiser balanserer det utviklende og det kritiske og hva som framstår som sentrale kilder til kunnskapsutvikling.

Forskning viser at det er visse kjennetegn ved skoler som lykkes med å oppnå høy skår på tester som har til hensikt å måle elevenes læringsutbytte. Slike kjennetegn er gjerne forklart gjennom variabler som effektivt, tydelig instrumentelt lederskap, fokus på faglige resultater, positiv skolekultur, høye forventninger til elever og ansatte, overvåking av progresjon på skolen, i klasserommet og hos elevene, involvering av foreldre gjennom å dempe negativ innflytelse, referansemålinger mot beste praksis, profesjonell utvikling av skolens personell og involvering av elevene gjennom rettigheter og plikter (Teddlie \& Reynolds, 2000). Lærerens opptreden i klasserommet ilegges i forskningen stor betydning og trekkes ofte fram som det mest betydningsfulle for elevenes læringsutbytte (Day, Stobart, Sammons \& Kington, 2006; Hattie, 2009; Reynolds et al., 2014).

Hargreaves og Fullan (2012) utfordrer forskningen som trekker fram læreren som den mest betydningsfulle faktoren for elevenes læring, og konsekvensen der ofte enkeltlæreren ansvarliggjøres. Som et alternativ foreslår de å bygge kapital gjennom å benytte seg av grupper og samfunnet rundt skolen som helhet. Ideen bygger på argumentasjon knyttet til at flere mennesker i lag er sterkere enn hvert enkelt individ (Hargreaves \& Fullan, 2012). Sett i lys av forskning som peker på kjennetegn ved skoler som oppnår gode resultater, vil det være interessant å studere praksiser på skoler som ser ut til å lykkes på nasjonale prøver. Er det for eksempel slik at det er enkeltlærerne på skolene som framstår som nøkkelen til suksess, eller kan det være andre forhold ved praksis som framstår som forklaringer? Schoefield (2007) og Gudmundsdottir $(1997,2001)$ påpeker at studier av gode case kan bidra med verdifull kunnskap som igjen kan anvendes som tankeredskap for andre som ønsker å bidra til utvikling og forbedring av egen praksis.

Med dette som bakteppe ønsker jeg i artikkelen å belyse følgende forskningsspørsmål:

Hva karakteriserer praksis på skoler som over tid har oppnådd gode resultater på nasjonale prøver, og hvordan utvikles praksis i møte med nasjonale prøver som element i skolens praksisarkitekturer?

Et hovedanliggende i artikkelen er å bidra med ny innsikt om hvordan skolenes praksiser utformes i et dynamisk samspill med de praksisarkitekturer som rammer inn praksisene. Spesielt fokuseres det på hvordan nasjonale prøver, som inngår i praksisarkitekturene, integreres i skolenes praksisutvikling. Videre rede- 
gjør jeg for praksisbegrepet og teorien om praksisarkitekturer, som er benyttet som et rammeverk i artikkelen for å forklare og forstå praksisutvikling.

\section{Praksisbegrepet og praksisarkitekturer}

Det er vanlig å snakke om praksis i entall, som for eksempel i form av skolens praksis, undervisningspraksis, ledelsespraksis o.l. Et hovedanliggende i teorien om praksisarkitekturer er at praksis sjelden bør forstås i entall, men at praksiser eksisterer i sammenheng med andre praksiser (Kemmis et al., 2014). Kvernbekk (2008, s. 14) hevder den vanlige oppfatningen av pedagogisk praksis tilsier at "praksis er et personliggjort og handlingsorientert begrep». Ved en slik tilnærming, som hun kritiserer, framstår praksis som noe som tilsynelatende tilhører én person eller én aktørgruppe som tenker og handler. Tilnærmingen til begrepet praksis som den brukes i denne artikkelen, er helhetlig og bygger på teorien om praksisarkitektur (Kemmis et al., 2014). Praksis er forstått som og avhenger av individets erfaringer, handlinger og intensjoner. Aktørene som engasjerer seg i en form for praksis, reproduserer ikke bare tidligere forståelser og handlinger, men i tillegg utvikler de ny kunnskap gjennom et samspill med strukturer og handlinger. Praksis som Kemmis et al. (2014) beskriver den, består av sayings, altså hva aktørene sier, tenker og uttrykker verbalt og non-verbalt, doings, som forstås som det som gjøres, eller i denne artikkelen det som sies at det gjøres, og relatings, som omhandler hvordan aktørene forholder seg til hverandre og omgivelsene rundt. Disse tre elementene i praksis henger sammen i et karakteristisk prosjekt som gjenspeiles i svaret aktørene gir på spørsmålet hva er det du gjør?

Praksiser, både individuelle og kollektive, formes av og former omkringliggende praksisarkitekturer. Praksisen er dannet og betinget av hendelser som er utenfor den enkelte person eller gruppe. Praksiser er gjort mulig gjennom praksisarkitekturer (Kemmis et al., 2014, s. 33). Praksisarkitekturene er de forutsetningene som gjør praksiser mulige og holder dem på plass. Blant annet består praksisarkitekturer av forskjellige kombinasjoner av dimensjoner som er beskrevet på denne måten:

- De kulturelle-diskursive forholdene er gjort mulige gjennom språket og de diskurser som benyttes i og om praksisen. Hva som sies, tenkes og uttrykkes av deltakerne i en praksis, oppstår i et semantisk rom med de individuelle sayings på den ene siden og de kollektive sosiale kulturellediskursive forholdene på den andre siden. Debatter, medieskapte forståelser og politiske utsagn om de nasjonale prøvene kan for eksempel forstås som tilhørende disse rammene.

- De materielle-økonomiske forholdene er de ressursene som muliggjør aktivitetene i en praksis. Disse styrer og muliggjør praksisens doings. 
Tilgjengelige ressurser som klasserom, møterom, antall elever, lærebøker etc. tilhører de materielle-økonomiske forholdene. De nasjonale prøvene i sin konkrete form kan også forstås som en del av disse rammene.

- De sosial-politiske forholdene er de ressursene som muliggjør forholdet mellom mennesker og det som beskrives som ikke-menneskelige objekter som forekommer i praksisen. Her kan det for eksempel handle om hvilke makt- og relasjonsmønstre som finnes. Hvordan fordeles for eksempel makt mellom rektor og lærere? Hva kjennetegner relasjonene mellom skolen og foreldrene? Hvem bestemmer hva?

Denne måten å forstå praksiser på legger vekt på dynamikken mellom individet, det sosiale og arrangementene som danner rammen for å gjøre det mulig å utføre praksis.

Kemmis et al. (2014) argumenterer for at det er forbindelser mellom praksiser. Forbindelsene utvikles gjennom praksisens lokalitet og spesifikke forhold mellom de ulike praksisene. Praksiser som oppstår i en bestemt lokalitet og situasjon kan videre utvikle seg til å danne praksisarkitekturer for andre praksiser. For eksempel kan en rektors ledelsespraksis inngå i praksisarkitekturen for lærernes undervisningspraksis. Slike forbindelser mellom praksiser er beskrevet som «ecologies of practices» i teorien om praksisarkitekturer (Kemmis et al., 2014, s. 44) oversatt til praksisøkologier i Vestheim (2017).

\section{Metode}

Forskningsstrategien i studien bygget på kvalitative casestudier. Sentralt for casestudier er at en studerer fenomener, som i dette tilfellet er praksiser, i sine naturlige kontekster (Bryman \& Bell, 2011; Stake, 1995). Hensikten var å utvikle forståelse for praksiser ved skoler som så ut til å være fordelaktige for et bredt utvalg elever med tanke på å oppnå gode resultater på de nasjonale prøvene. Empirien ble samlet inn fra et strategisk utvalg av sju skoler som over minimum tre år hadde oppnådd bedre resultater på nasjonale prøver enn det som kunne forventes ut ifra inntekts- og utdanningsnivået på kommunenivå (se Langfeldt, 2015, s. 21-24 for nærmere beskrivelse av de statistiske metodene). Skolene var fordelt på fire fylker og seks kommuner. Fire av skolene dekket 1.10. trinn, to 1.-7. trinn og én 8.-10. Skolenes størrelse varierte i området 120 320 elever. Antall lærere på skolene varierte mellom 14 og 26 alt etter størrelsen på elevgruppen.

I hovedsak bygde det empiriske grunnlaget på kvalitative singel- og gruppeintervjuer med henholdsvis 7 rektorer (+ inspektører i to tilfeller), ca. 60 lærere fordelt på skolene og etter om de hovedsakelig underviste på små-, mellom- eller ungdomstrinnet. Dette ble ansett som et hensiktsmessig utvalg (Creswell, 2007, s. 100) egnet til å kaste lys over studiens forskningsspørsmål. 
Den tematiserte intervjuguiden fokuserte på ulike forhold som kunne kaste lys over skolenes praksiser. Eksempler på tema kan være tilpasset opplæring, lærerkompetanse, pedagogisk grunnsyn, skoleutvikling, ledelse og erfaringer med nasjonale prøver. For øvrig utviklet intervjuene seg i tråd med det som var naturlig i de ulike intervjusituasjonene.

For å synliggjøre hvordan jeg har utviklet og kommet fram til resultatene, vil jeg beskrive de ulike grepene som er gjort i analyseprosessen. Først er det sentralt å forstå at analysen er utført i samspillet mellom teori og empiri, gjerne omtalt som en abduksjon (Alvesson \& Sköldberg, 2008, s. 55-65). Intervjuene ble transkribert og analysert etter prinsipper fra konstant komparativ analysemetode (Boeije, 2002; Corbin \& Strauss, 2008).

Etter at intervjuene var transkribert, foretok jeg en åpen koding. Intervjuene ble lest i sin helhet, og utsagn som ble oppfattet som relevante for å kaste lys over studiens problemstilling, ble markert og skrevet ned. Markeringene ble siden analysert og bearbeidet til stikkord, teori- og empiridrevne begreper eller korte sitater som kunne være oppsummerende for lengre utsagn. Med utgangspunkt i de tidlige analysene ble det videre utviklet foreløpige kategorier som senere ble analysert videre gjennom spørsmålene hvor, hvordan og hvorfor?

I neste steg ble det foretatt en komparativ analyse på tvers av intervjuene innen samme gruppe, som i dette tilfelle var ensbetydende med samme skole. Sentralt i denne prosessen var å belyse likheter og forskjeller mellom intervjuene for å finne kategorier som kunne være beskrivende for hele skolen som kasus. Viktige spørsmål jeg stilte meg her var om lærere på småtrinnet, mellomtrinnet og ungdomstrinnet snakker om det samme? Hva er likheten og forskjellen mellom intervjuene? Er kategoriene brukbare for å beskrive et felles syn for de intervjuede? Hvilke felles kategorier kan brukes for best mulig å beskrive lærernes og rektorenes forståelser og handlinger?

Etter utarbeiding av kategorier for den enkelte skole ble det foretatt sammenlikninger mellom skolene. Sentralt i dette steget var å utvikle kategorier som framstod som representative for skolene. Kategoriene er spesifisert gjennom resultatene og danner samtidig strukturen for presentasjonen av funnene i studien.

Analysene og kategoriene er diskutert og utviklet i dialog med andre forskere for å styrke den kommunikative validiteten i studien (Kvale \& Brinkmann, 2009, s. 258). Samtidig ble foreløpige analyser og resultater presentert på seminarer og workshops der forskere og representanter fra praksisfeltet og de ulike kasusskolene møttes. I den settingen hadde de intervjuede skolelederne og lærerne mulighet til å korrigere og gi tilbakemeldinger på om de kunne kjenne seg igjen i den karakteristikken og tolkningen som ble framstilt.

Studien er gjennomført med utgangspunkt i sju kasus, og intervjuene er gjennomført i løpet av én til to dager på den enkelte skole. Både antall skoler og lengden på datainnsamlingen kunne bidratt til å styrke studiens kvalitet. Ideelt sett kunne gjerne feltarbeidet foregått over en lengre tidsperiode i stedet for 
gjennom ett kort dykk inn i skolenes tenkning og praksis slik som i denne studien. Bruk av andre kilder og metoder for innhenting av empiri kunne også bidratt til annen kunnskap om skolenes praksis.

\section{Analyse og resultater}

Gjennom analyseprosessen ble det utviklet tre kategorier som framstår som betydningsfulle dimensjoner i skolenes praksiser: læringspraksiser, utviklingspraksiser og kollektive praksiser. Under presenteres først sitater som representerer de kategoriene som er utviklet. Resultatene følges deretter fortløpende opp med diskusjon.

\section{Læringspraksiser}

Vi har aldri trent til prøvene, det har vi aldri gjort. Og det har vi jo hørt i media at skjer enkelte steder. Men det har i hvert fall vi aldri gjort. (Lærer)

Vi skal prøve å gjøre en best mulig jobb for at vi skal få elevene våre best mulig. Det går blant annet på at de skal få den utdanningen de har krav på, og tilpasset opplæring. (Lærer)

Som vår rektor prøver å si: Nå må dere huske på at det ikke bare er lesing og skriving. Det er også opplevelser, inntrykk og uttrykk på mange måter. Det har gått igjen i forhold til læring. (Lærer)

Jeg er ikke så opptatt av det, jeg er opptatt av at ungene lærer. Men kanskje disse to årene hvor vi har gjort det litt dårligere da, så har jeg vært bevisst på det der med å gå bakom talla og - og prøve å forstå det i forhold til hva slags unger vi har. Det er dem vi skal ha videre. (Rektor)

Men jeg vil påstå at vi er ikke opptatt av å markere oss i forhold til enkeltresultat på nasjonale prøver. Vi driller ikke eller noe sånt, vi er veldig opptatt av at det skal holdes på et plan der det skal være en del av læringen. Det skal ikke være en enkeltstående del, det skal være en del av den totale læringen. (Rektor)

For det første så er det ikke jeg som gir læring! Det er lærerne som gir dem (elevene) læring. Jeg legger til rette for at lærerne skal lære. Så jeg tenker det er den til rettelegginga da, ikke sant, og da tenker jeg på dette her med at vi har fellesskap. Vi har blikk for den enkelte. Legge til rette for det, i forhold til den kompetansen som lærerne har og de ressursene som vi har tilgjengelig. (Rektor)

Læringspraksisene kommer til uttrykk i skolenes praksiser både gjennom det som sies, gjennom det som gjøres og på måten skolen relaterer sin praksis til både interne og eksterne forhold som kan være av betydning for ulike sider ved skolens læring. Læringspraksisene innebærer fokus på elevenes læring, lærernes læring og læring om hvordan skolen som helhet kan utvikles ved evaluering av forhold som inngår i skolenes praksisarkitekturer (Kemmis et al., 2014; Vestheim, 2017). 
Læringspraksisene er knyttet til elevenes læring ved at skolene arbeider med å være tett på og følge opp den enkelte elev i skolehverdagen. Å være tett på elevenes læring kan innebære at skolen kan sette inn tiltak der lærerne mener de har behov for det. Elevperspektivet kommer også til uttrykk i læringspraksisene gjennom måten prøveresultatene blir brukt som utgangspunkt i kollegiet for å vurdere på hvilke områder skolen kan bedre sin praksis for at elevene i større grad skal nå målene i læreplanen. Også fra et ledelsesperspektiv står elevenes læring sentralt. Rektorene i studien hevder at deres rolle er å tilrettelegge for læring slik at lærerne skal ha gode forutsetninger for sitt arbeid med elevene i klasserommet.

Lærernes læring uttrykkes ved at skolene i studien vektlegger samarbeid, diskusjon og refleksjon. Lærerne i studien hevder at en velfungerende praksis ved skolen avhenger av at de arbeider sammen og drar i samme retning, at de er samarbeidsorienterte. Lærernes erfaringer fra klasserommet og arbeidet med elevens læring er erfaringer som deles blant de ansatte. De nasjonale prøvene inngår i disse praksisene. Prøvene er blant annet brukt som redskap til å lære mer om de grunnleggende ferdighetene prøvene bygger på, og hvordan prøvene og de grunnleggende ferdighetene henger sammen med målene i læreplanen. Rektorene bidrar med tilrettelegging for lærernes læring, slik at elevene i siste ledd skal ha så gode rammer for læring som mulig. Relasjonen mellom lærerne og rektorene framstår dialektisk der lærerne peker på tydelig ledelse som en premiss for at skolen lykkes med prøvene. Det framkommer av studien at lærerne opplever at rektor stiller krav til engasjement i skolens praksisutvikling. Rektorene på sin side anser det som sin oppgave å legge til rette for lærernes læring.

Innføringen av de nasjonale prøvene kan anses som at praksisarkitekturene for grunnskolen i Norge ble endret. Endringer i praksisarkitekturene medfører i sin tur endringer i praksiser, da disse er vevd sammen i hverandre slik at endringer i én del vil medføre endringer i den andre (Kemmis et al., 2014). Endringer i praksisarkitekturene har manifestert seg på flere måter. Forskning viser at nasjonale prøver bidro til nye kulturelle-diskursive rammer gjennom debatter blant politikere, fagforeninger som Utdanningsforbundet og aktører i skolen (Mausethagen, 2013b). De materielle-økonomiske rammene ble endret ved at prøvene ble tilført som en ressurs de involverte i skolen måtte forholde seg til (Mausethagen, 2013a). De sosial-politiske rammene endret seg ved at prøvene fikk betydning for relasjonene mellom alle aktører som har en eller annen form for tilknytning til skolen (Elstad, Hopmann \& Langfeldt, 2008). De sosial-politiske sidene av praksisarkitekturene kommer blant annet til uttrykk gjennom intensjonene med prøvene. Fra Utdanningsdirektoratet er det uttrykt at resultatene fra prøvene skal brukes til utvikling av skolens praksis med mål om å bedre elevenes kompetanse i grunnleggende ferdigheter. En dimensjon som ikke er eksplisitt uttalt, men som likevel kommer til uttrykk, er økt fokus på konkurranse og rangering mellom skoler, kommuner og fylker. Fylkes-, 
kommune- og skoleresultater ligger tilgjengelig i nettressursen Skoleporten.no, og kan med få tastetrykk framstilles komparativt. Slike forhold inngår dermed i skolenes praksisarkitekturer som har betydning for de handlingene som blir utført av aktørene der. Funn fra min studie viser at disse praksisarkitekturene på flere måter blir gjeldende i skolenes læringspraksiser. Funnene gjenspeiler både skepsis og uttrykt avstand til de nasjonale prøvene som system og fenomen. Til tross for en uttalt skepsis til nasjonale prøver vurderes og reflekteres det kollektivt på skolene i studien over på hvilken måte de nasjonale prøvene skal virke inn på allerede etablerte, eksisterende praksiser. I det intersubjektive rommet er det rom for skepsis, men også imøtekommelser hvis aktørene mener det er grunnlag for praksisendringer. De nasjonale prøvene blir gjenstand for meningsutveksling og utvikling av et språk som ikke kunne vært mulig uten at prøvene ble innført. Prøvenes funksjon blir diskutert blant skolens ansatte. Prøvene blir en del av praksisene både i det enkelte klasserom, men også i skolens øvrige praksiser gjennom at testene danner en premiss for å diskutere prøveresultater, hva de kan lære av prøvene, og hvordan både prøvene og skolens resultater kan bidra til utvikling av skolens praksiser.

Et spørsmål som gjerne stilles i forbindelse med skoler som lykkes med å oppnå høy skår på nasjonale prøver, er hvorvidt skolen spisser sine undervisningspraksiser mot det som skal testes på prøvene. Det er ikke uten grunn at slike spørsmål stilles. Forskning viser at resultatfokuserte skoler er opptatt av læring gjennom å fokusere på faglig læringsutbytte og å maksimere tiden som brukes til dette formålet (Reynolds et al., 2014). Det å være opptatt av elevenes faglige læring kan gi utslag i form av ulike praksiser. Internasjonal forskning viser at dersom fokus på testresultatene dominerer, kan dette føre til praksiser i skolen som går på bekostning av skolens totale samfunnsmandat (Berliner, 2011; Biesta, 2009). Slike praksisendringer kan være å tilrettelegge skolens praksis ensidig med det mål for øye å skape best mulig resultater på det som skal måles, såkalt «teaching to the test». Funnene i denne studien kan også forstås som at skolene er opptatt av både testresultater og faglig læringsutbytte. Dette trenger derimot ikke å bety at praksisene som kommer til uttrykk kan sammenliknes med det å ensrette undervisningen inn mot de nasjonale prøvene. Slik jeg tolker og forstår praksisene som beskrives av rektorene, lærerne og elevene, er skolene mer læringsorienterte enn resultatorienterte. At skolene er læringsorienterte betyr i denne sammenheng at resultatene på de nasjonale prøvene ikke er et mål i seg selv, men at skolene kontinuerlig søker å utvikle praksiser der målsettingen er å bedre kvalitetene ved flere sider av skolens virksomhet som til sist skal komme elevene til gode.

Læringspraksisene er nært knyttet til utviklingspraksisene. Mens læringspraksisene handler om ulike sider av læring for elever, lærere og skolen som helhet, handler utviklingspraksisene på sin side om hvordan skolene i studien utvikler sine praksiser, slik det framkommer i neste underkapittel. 


\section{Utviklingspraksiser}

Vi har hatt en grunnpedagogikk over mange år. (Lærer)

Vi er en ganske konservativ skole. Vi er ikke de første til å hoppe på nye trender. (Lærer)

Samtidig som en er faglig oppdatert og tar til seg trender i tiden, for å si det sånn, så har en også rom for å tilpasse det. (Lærer)

En blir vant med å tenke hele tiden - hva gjør jeg, hvorfor gjør jeg det [...] En kan ikke snu bunken det neste året - nå begynner vi på nytt igjen. Det er hele tiden refleksjon rundt arbeidssituasjonen. (Lærer)

Jeg synes vi har vingla mye i norsk skolepolitikk og i norsk skolesatsing. Og ikke alt av det trenger vi å gape over fullt og helt, jeg har sagt det rett ut til mine medarbeidere, at ja, dette har vi. Dette kan vi jobbe trygt med, fortsette sånn som vi har gjort. Og ting som vi ser fører fram, ting som er fremmende for å nå målene i Kunnskapsløftet, ser jeg ingen grunn til å endre på. (Rektor)

Men så er det metodefrihet i forhold til å komme til målet. Det er det viktig å dyrke. Og det er ulike tilnærminger - hvis du hadde fulgt ulike klasser i ulike fag - i forhold til hvordan de organiserer klassen, både hvordan de organiserer seg i klasserommet, men også innenfor andre rom de har tilgjengelig. Det er nok stor forskjell fra lærer til lærer, men det lar vi det være. For vårt utgangspunkt er at hvis de «leverer varen» og lykkes med de metodene de har, så er det godt nok. Vi har veldig fokus på balanse mellom rettighet/plikter og ansvar/frihet, bortsett fra grunnmuren vår. (Rektor)

Slik det framkommer av studiens empiri, driver skolene utvikling av praksis gjennom å vurdere og evaluere allerede etablerte praksiser. Å vurdere etablerte praksiser kan handle om å kritisk diskutere og reflektere over hva som fungerer godt, og hva som eventuelt kan endres til noe bedre. Utviklingspraksisene har ofte som mål eller utgangspunkt at eventuelle endringer i praksisene skal bidra positivt til elevenes læring. Utviklingen skjer i spennet mellom det som kan karakteriseres som stabilitet og utvikling. Stabiliteten har sitt utspring i aktørenes tro på allerede eksisterende praksiser innarbeidet på skolene. Skolene hevder å ha en form for grunnpedagogikk som de har holdt på i mange år. Utvikling på sin side innebærer evaluering av de etablerte praksisene, og om det eventuelt kan være behov for endringer. Målet er å være faglig oppdatert, men samtidig løftes det fram at det er rom for å bearbeide eventuelle nye trender og slik sett bruke det handlingsrommet skolene har.

Utviklingen er gjerne forankret i skolens kontekst, gjennom skolens egne initiativer. Analysene viser at skolene stadig vurderer trender og styringssignaler som er initiert fra utsiden av skolen, altså ytrestyrte strategier. Norsk skolepolitikk kritiseres for å vingle for mye, og at det dermed stadig er forventet at skolene skal endre arbeidsmetoder eller retning i arbeidet sitt. Slik det kommer til uttrykk i funnene vil heller skolene vurdere om de nye trendene vil gjøre dem bedre, eller om skolen kan fortsette med det arbeidet de allerede er i gang med, altså beholde eksisterende praksis. 
Et annet kjennetegn ved skolenes praksiser er at både lærere og rektorer ved skolene gir uttrykk for en kontinuitet der noen regler, normer og forestillinger om deres egen praksis bidrar til å skape sammenheng. At skolene til tider velger å stole mer på egne praksiser enn ønsker om praksisendringer fra eksterne parter, vitner om at dette er skoler med stor tro på egen praksis. Skolene har erfart at de eksisterende praksisene har ført fram, noe blant annet resultatene på de nasjonale prøvene blir brukt som bevis på. Til tross for troen på allerede eksisterende praksiser, er ikke det til hinder for videre utvikling. Lærerne og rektorene utviser derigjennom en kritisk holdning til potensielle endringer forsøkt initiert fra ytre hold. Utvikling handler dermed om å vurdere hva som kan eller bør endres av den eksisterende praksisen. Det som blir ansett som å fungere godt kan tas med videre, mens praksiser som tilsynelatende kan bli bedre, vektlegges i skolenes videre utvikling.

Høye forventninger til ansatte og elever er ansett som et sentralt anliggende for å oppnå gode resultater (Reynolds et al., 2014; Teddlie \& Reynolds, 2000). Et spørsmål som da kan stilles er om forventningene skal knyttes til resultatene, eller om forventningene kan relateres til andre sider ved skolens praksiser? Høye forventninger handler ikke nødvendigvis om resultater i form av høy skår på de nasjonale prøvene. Forventningene er heller knyttet til at det eksisterer en form for intern justis og forventning til at skolens ansatte skal engasjere seg og delta aktivt i utvikling av skolens praksis. Forventningene omsettes i praksis gjennom blant annet krav til aktiv deltakelse i fellesskap der diskusjon og refleksjon er bærebjelker for å utfordre eksisterende praksis og ytre praksisarkitekturer. $\AA$ inneha høye forventninger til skolens ansatte er dermed ikke basert på en instrumentell tankegang med høy skår på nasjonale prøver som viktigste mål, men forventninger til deltakelse. Funnene indikerer at det å ha høye forventninger har konsekvenser for blant annet hvordan skolehverdagen organiseres, og hvordan det tilrettelegges for utvikling av skolens praksis. Dette kan forstås som kollektive praksiser.

\section{Kollektive praksiser}

Vi er ikke noen småbedrifter i skolen. Vi er en helhet, og da er det skolen som jobber med det. (Lærer)

Vi prøver å være mest mulig like. Vi er jo ikke roboter, men vi vet retningslinjene i alle fall. Så prøver alle sammen ... vi har jo godtatt og godkjent at sånn skal vi prøve å få det til, så får vi alle ut ifra våre evner prøve å holde på det vi har blitt enige om da. (Lærer)

Det handler om å gå i samme retning, men samtidig erkjenne at veien er bred. (Rektor)

De kollektive praksisene handler om hvordan læringspraksisene og utviklingspraksisene er forankret i skolenes organisering, og kommer derfor til uttrykk på flere måter. Skolene i studien framstår som «vi-skoler» der det er skolen som 
enhet som skal løftes heller enn den enkelte lærer med sin klasse og sitt klasserom. Kollektiviteten medfører at de ansatte i skolene framstår som trygge på de valgene de foretar og den pedagogiske retningen de fører skolen i. Når det oppstår trender eller skolen blir tilført nye oppgaver, vurderes det kollektivt hvordan dette skal håndteres, hvordan det kan gjøre skolens praksis bedre, eller om skolene kan fortsette med de praksisene de allerede har.

I de kollektive praksisene balanseres utforming av skolens praksiser mellom rektor som leder, lærerne og andre eksterne aktører som kan bidra i skolens virksomhet. Det er rektorene gjennom sitt ansvar og sin maktposisjon i hierarkiet som framstår som premissleverandør og tilrettelegger for skolens praksiser. En side ved de kollektive praksisene er at skolenes utvikling blir besluttet på grunnlag av diskusjoner der flere parter er involverte i prosessen. Dette kan forstås som at skolens mål og retning er basert på en kollektiv forståelse, men at måten skolen arbeider mot disse målene på, kan variere. Fokus på kollektive prosesser der det er rom for meningsutveksling, refleksjon og diskusjon innad i kollegiet, resulterer ofte i løsninger som samtlige av skolens ansatte skal forholde seg til. Det er godt dokumentert at kollektivt orienterte skoler gjerne oppnår gode resultater (DuFour \& Marzano, 2011; Hargreaves, 1996; Vestheim, 2014).

I praksisene framstår det som sentralt å samles i møter for å diskutere og reflektere over ulike sider ved skolens praksis og praksisarkitekturer. I møtene forhandles og reforhandles praksisene i møte med både interne og eksterne arrangementer. Eksisterende praksiser evalueres stadig innenfor rammer av kulturelle-diskursive, materielle-økonomiske og sosial-politiske ressurser som er tilgjengelige i skolens praksisarkitekturer (Kemmis et al., 2014).

\section{Sammenfattende diskusjon}

Artikkelen bygger på en teoretisk grunnantakelse om at praksiser utvikles og oppstår gjennom et dynamisk samspill med aktuelle praksisarkitekturer. I dag er forventninger og krav til at skoler skal stå til ansvar for elevers faglige læringsutbytter i fag så vel som i de grunnleggende ferdighetene som måles gjennom nasjonale prøver. Dette kan forstås som ansvarliggjøring (Elstad et al., 2008; Hopmann, 2008; Jacob, 2005). Når krav og forventninger til skolen endres, medfører dette endringer av rammene for den praksis som utvikles. Endringer i måten skolen mål- og resultatstyres på, har gjort at begrep som «høyt læringstrykk» har oppstått (kulturelle-diskursive rammer) gjennom fokus på resultater og måloppnåelse med ansvarliggjøring som middel (sosial-politiske rammer), samt økende sentralt og politisk styrt utvikling av skolen. Denne studien gir innblikk i hvordan skolene forhandler og reforhandler egen praksis i møte med disse strukturene som kan forstås som praksisarkitekturer. Det ligger i ansvarliggjøringens prinsipp at noen, det kan være enten skoleledere eller lærere, skal stå til ansvar for de resultater som foreligger, en såkalt teknisk forståelse av 
ansvarliggjøring (Johnsen, 2010). I enkelte land med andre utdanningssystemer enn det som tradisjonelt har kjennetegnet det norske, kan bruk av insentiver og sanksjoner i ulike former benyttes for enten å belønne eller å straffe, alt etter skolenes resultater (Hargreaves \& Fullan, 2012; Jacob, 2005). I det norske utdanningssystemet er det ikke slik at resultatene på de nasjonale prøvene har direkte konsekvenser for verken skolen, skolens ledelse, lærerne eller elevene. Til tross for fravær av ytre sanksjoner og insentiver, vitner funnene i studien om at skolene likevel har som mål å stadig utvikle skolens praksiser, vel å merke dersom de ansatte i fellesskap finner at det er nødvendig med en korrigering, det vi kan forstå som en indre kollektiv ansvarliggjøringspraksis som tar utgangspunkt $\mathrm{i}$ at det er skolen som kollektiv enhet som tar ansvar for egen skoleutvikling.

Praksisene på skolene er kjennetegnet ved at fokuset er rettet mot skolen som en samlet enhet. Det erkjennes at lærerne har ulike styrker og svakheter, og at alle ikke kan være like gode på alt. I motsetning til å ansvarliggjøre den enkelte lærer utvikles praksiser som har til hensikt å styrke skolen som enhet. DuFour og Marzano (2011) hevder også at ledere som lykkes med å oppnå resultater i sin organisasjon, innser at dette ikke er oppgaver som kan løses av enkeltpersoner, men at prosessen krever at flere må involveres i samarbeidende team gjennom delt ledelse. Praksisene som framstår som kollektive heller enn individorienterte, kan minne om det som omtales av Hargreaves og Fullan (2012) som profesjonell kapital. Den profesjonelle kapitalen i en organisasjon kjennetegnes nettopp av at den egner seg til å anerkjenne styrken i fellesskapet. Erkjennelsen av betydningen av fellesskap innebærer at organisasjonens kapital må være i omløp og deles mellom de ansatte. Funnene som presenteres i denne studien gjennom lærings-, utviklings- og kollektive praksiser, kan forstås som og representere en slik organisasjonstankegang. Det er sannsynlig at for eksempel lærere som ikke har de beste forutsetningene for å lykkes, vil få styrket sine evner gjennom å bli sosialisert inn i samarbeidsorienterte skoler. En annen måte å forstå hvordan ansvarligheten kan framstå mindre synlig på, er at skolene i studien framstår som sterke kollektiver. Et sterkt kollektiv kan bidra til at opplevelsen av ansvarliggjøring ikke framstår som individuelt rettet mot enkeltlærere, men at den rettes mot skolen som organisasjon. Det kan bety at det er skolen med alle dens ansatte med ulike roller som tar ansvaret heller enn den enkelte lærer.

Som påpekt innledningsvis viser forskning at praksiser endres som en konsekvens av økt styring gjennom ansvarliggjøring (Hermansen \& Mausethagen, 2016; Mausethagen, 2013a, 2013b). Gunnulfsen og Roe (2018) antyder blant annet at nasjonale prøver blir anvendt og forstått ulikt blant lærere i norsk skole. Resultatene deres viser på den ene siden at halvparten av de undersøkte lærerne opplevde å ta ansvar for å følge opp elevens resultater på de nasjonale prøvene. På den annen side rapporterte kun femten prosent at resultatene fra prøverapporten ble benyttet i undervisningssammenheng. Funn fra min studie 
indikerer at nasjonale prøver er et verktøy som bidrar til at skolens ansatte samles nettopp for å diskutere og reflektere over ulike sider ved skolens praksis, deriblant undervisning. Diskusjonene og refleksjonene rundt nasjonale prøver bidrar til en profesjonell og produktiv dialog der praksis utvikles i lag med andre med hensikt på å utvikle skolen deres til stadig å bli bedre. Målet med å utvikle praksis er noe annet enn å oppnå høy skår på de nasjonale prøvene isolert sett, men kan heller anses å stadig opptre som en lærende organisasjon. Mens de nasjonale prøvene blant mange betraktes som en ytrestyrt strategi for styring av skolen, kan prøvene i denne studiens kontekst heller forstås som et verktøy for indrestyrt praksisutvikling. At skolene som er representert i studien i utgangspunktet kan oppfattes som «suksessfulle», kan muligens forklares med at de nettopp evner å oversette det ytre styrte og gjøre dette til en del av deres egen praksis.

For videre forskning og kunnskapsutvikling kunne det være hensiktsmessig å utføre feltarbeid med lengre varighet og andre metoder enn de som er benyttet i denne studien. For eksempel kunne det være hensiktsmessig å vektlegge datainnsamling med utgangspunkt i kvalitative observasjoner. En slik metodisk tilnærming til å studere praksisene kunne bidratt til økt forståelse for hvordan informantenes redegjørelse i muntlig form kunne utspille seg i konkrete hverdagslige situasjoner.

En annen metodisk innfallsvinkel kunne være å studere skolers «collective efficacy» med tanke på om dette på et generelt grunnlag virker inn på resultatene på nasjonale prøver.

\section{Om forfatteren}

Ole Petter Vestheim er førsteamanuensis i pedagogikk ved Nord universitet. Hans forskningsinteresser omfatter blant annet skoleutvikling, læreres yrkesbaner og lærerutdanning.

Institusjonstilknytning: Fakultet for lærerutdanning og kunst- og kulturfag, Nord universitet, Postboks 1490, 8049 Bodø.

E-post: ole.p.vestheim@nord.no

\section{Referanser}

Alvesson, M. \& Sköldberg, K. (2008). Tolkning och reflektion: vetenskapsfilosofi och kvalitativ metod (2. uppl.). Lund: Studentlitteratur.

Barrett, B. D. (2009). No Child Left Behind and the Assault on Teachers' Professional Practices and Identities. Teaching and Teacher Education: An International Journal of Research and Studies, 25(8), 1018-1025.

Berliner, D. (2011). Rational responses to high stakes testing: the case of curriculum narrowing and the harm that follows. Cambridge Journal of Education, 41(3), 287-302. 
Biesta, G. (2009). Good education in an age of measurement: on the need to reconnect with the question of purpose in education. Educational Assessment Evaluation and Accountability (Formerly: Journal of Personnel Evaluation in Education), 21(1), 33-46.

Boeije, H. (2002). A purposeful approach to the constant comparative method in the analysis of qualitative interviews. Quality \& Quantity, 36(4), 391-409.

Bryman, A. \& Bell, E. (2011). Business research methods. Oxford: Oxford University Press.

Corbin, J. M. \& Strauss, A. L. (2008). Basics of qualitative research: techniques and procedures for developing grounded theory. Thousand Oaks, Calif.: Sage.

Creswell, J. W. (2007). Qualitative inquiry \& research design: choosing among five approaches. Thousand Oaks, Calif.: Sage.

Day, C., Stobart, G., Sammons, P. \& Kington, A. (2006). Variations in the work and lives of teachers: relative and relational effectiveness. Teachers and Teaching, 12(2), 169-192.

DuFour, R. \& Marzano, R. J. (2011). Leaders of Learning: How District, School, and Classroom Leaders Improve Student Achievement. ERIC.

Elstad, E., Hopmann, S. \& Langfeldt, G. (2008). Ansvarlighet i skolen: Politiske spørsmål og pedagogiske svar. Oslo: Cappelen akademisk forlag.

Gudmundsdottir, S. (1997). Introduction to the theme issue of narrative perspectives on research on teaching and teacher education. Teaching and Teacher Education, 13(1), 1-3.

Gudmundsdottir, S. (2001). Narrative Research in School Practice. I I. V. Richardson (red.), Fourth Handbook for Research on Theaching (s. 226-240). New York: Macmillan.

Gunnulfsen, A. E. \& Roe, A. (2018). Investigating teachers' and school principals' enactments of national testing policies: A Norwegian study. Journal of Educational Administration, 56(3), 332-349.

Hargreaves, A. (1996). Læererarbeid og skolekultur: lareryrkets forandring i en postmoderne tid. Oslo: Ad notam Gyldendal.

Hargreaves, A. \& Fullan, M. (2012). Professional capital: transforming teaching in every school. London: Routledge.

Hattie, J. (2009). Visible learning: a synthesis of over 800 meta-analyses relating to achievement. London: Routledge.

Hermansen, H. \& Mausethagen, S. (2016). Når kunnskap blir styrende: Læreres rekontekstualisering av nye kunnskapsformer. Acta Didactica Norge, 10(2), 92-107.

Hopmann, S. T. (2008). No Child, No School, No State Left behind: Schooling in the Age of Accountability. Journal of Curriculum Studies, 40(4), 417-456.

Jacob, B. A. (2005). Accountability, incentives and behavior: the impact of high-stakes testing in the Chicago Public Schools. Journal of Public Economics, 89(5-6), 761-796. doi: https://doi.org/10.1016/j.jpubeco.2004.08.004

Johnsen, Å. (2010). Resultatstyringens mytologi: hvorfor bruker forvaltningen mål- og resultatstyring når dette er så omstridt? Nordiske organisasjonsstudier, 12(1), 5-28.

Kemmis, S., Wilkinson, J., Edwards-Groves, C., Hardy, I., Grootenboer, P. \& Bristol, L. (2014). Changing practices, changing education. Springer.

Kvale, S. \& Brinkmann, S. (2009). Det kvalitative forskningsintervju. Oslo: Gyldendal akademisk.

Kvernbekk, T. (2008). MacIntyre, praksis og undervisning. I T. M. Guldal, O. F. Lillemyr, G. Løkken, N. Naastad \& F. Rønning (red.), FoU i Praksis. Rapport fra konferanse om praksisrettet FoU i lererutdanning (s. 13-28). Trondheim: Tapir akademisk forlag.

Langfeldt, G. (2015). Skolens kvalitet skapes lokalt: presentasjon av funn fra forskningsprosjektet "Lœrende regioner". Bergen: Fagbokforlaget.

Lowrie, T. \& Diezmann, C. M. (2009). National numeracy tests: A graphic tells a thousand words. Australian Journal of Education (ACER Press), 53(2), 141-158. 
Mausethagen, S. (2013a). Reshaping teacher professionalism: an analysis of how teachers construct and negotiate professionalism under increasing accountability. Doktoravhandling, Høyskolen i Oslo og Akershus, Oslo.

Mausethagen, S. (2013b). Talking about the test. Boundary work in primary school teachers' interactions around national testing of student performance. Teaching and Teacher Education, 36(0), 132-142.

Mausethagen, S., Prøitz, T. \& Skedsmo, G. (2018). Teachers' use of knowledge sources in 'result meetings': thin data and thick data use. Teachers and Teaching, 24(1), 37-49. doi: https://doi.org/10.1080/13540602.2017.1379986

Reynolds, D., Sammons, P., De Fraine, B., Van Damme, J., Townsend, T., Teddlie, C. \& Stringfield, S. (2014). Educational effectiveness research (EER): a state-of-the-art review. School Effectiveness and School Improvement, 25(2), 197-230. doi: https://doi.org/10.1080/09243453.2014.885450

Schoefield, J. W. (2007). Increasing the generalizability of qualitative researc. I I. M. Hammersley (red.), Educational research and evidence-based practice (s. 181-203). London: Sage Publications.

Stake, R. E. (1995). The art of case study research. Thousand Oaks, Calif.: Sage.

Stauffer, S. D. \& Mason, E. C. M. (2013). Addressing Elementary School Teachers' Professional Stressors: Practical Suggestions for Schools and Administrators. Educational Administration Quarterly, 49(5), 809-837. doi: https://doi.org/10.1177/0013161x13482578

Teddlie, C. \& Reynolds, D. (2000). The international handbook of school effectiveness research. London: Psychology Press.

Tveit, S. (2014). Educational assessment in Norway. Assessment in Education: Principles, Policy \& Practice, 21(2), 221-237. doi: https://doi.org/10.1080/0969594X.2013.830079

Utdanningsdirektoratet (2016). Nasjonale prøver. Hentet 28.01.2016 fra http://www.udir.no/Vurdering/Nasjonale-prover/

Vestheim, O. P. (2014). "Slik blir det til at hele flokken løfter seg. Det er ikke opp til enkeltlærere!": en kasusstudie av praksis på skoler i områder med lavere utdannings- og inntektsnivå med gode resultater på nasjonale prøver. I A.-L. Østern (red.), NAFOLyearbook 2014: Once a teacher - always a teacher (s. 175-193). Bergen: Fagbokforlaget.

Vestheim, O. P. (2017). Nasjonale prøver - fra "tvangstrøye" til verktøy i utvikling av skolens praksis. Doktorgradsavhandling, Norges teknisk- naturvitenskapelige universitet, Trondheim.

Vestheim, O. P. \& Lyngsnes, K. M. (2016). A study of Norwegian schools achieving good national test results. International Journal of Educational Research, 79, 1-9. doi: https://doi.org/10.1016/j.ijer.2016.06.005 